\title{
COVID-19 STRENGTHENS THE SOLIDARITY AND ASSOCIATION OF SOUTHEAST ASIAN NATIONS - JAPAN COOPERATION
}

\author{
Mohd Ikbal Mohd Hudal, Siti Noor Adillah Masrol ${ }^{2}$
}

This article examines the initiatives of The Association of Southeast Asian Nations (ASEAN) and Japan through the cooperation of Government to Government (G2G) and the Special ASEAN Summit to combat the pandemic collectively. The initial cooperation through the coordinated "Integrated Recovery Plan" has been very significant for the future of ASEAN and the resilience of a post-COVID-19 world by way of maintaining market stability in order to avoid the potential risk of economic recessions and public health emergencies. This synergism is seen as one of the best mechanisms to help ASEAN in ensuring socio-economic activities are restored and the welfare of about 600 million people is addressed. This research found that ASEAN Plus Three (APT) cooperation should formulate a Regional Recovery Plan and emphasize that the continuity of the supply chain should be maintained to ensure a smooth flow of food and medical supplies. Secondly, APT cooperation needs to be committed to the continuation of opening up markets, maintaining normal trade, services and investment flows in order to continue strengthening regional economic resilience. Thirdly, APT needs to formulate a plan that focuses not only on financial aspects (post-COVID-19 economic recovery) but also on social security networks, food security and education.

Keywords: ASEAN Plus Three (APT), Japan, Solidarity, Cooperation, COVID-19

\section{INTRODUCTION}

The fight against coronavirus disease 2019 (COVID-19) is not over yet. A year after the outbreak started in Wuhan, China, in December 2019, it has infected 85.5 million people and sacrificed 1.85 million lives globally ${ }^{3}$. In Southeast Asia, the Association of Southeast Asian Nations (ASEAN) suffered 1.56 million cases and 35 thousand deaths since their first confirmed cases were reported in mid-January $2020^{4}$. This number pales in comparison to other regions such as the Americas and Europe, despite being among the most rapidly growing region in the world. Although the fatality rate of COVID-19 is comparatively lower than other deadly

\footnotetext{
${ }^{1}$ Corresponding Author: Senior Lecturer, Strategic Studies and International Relations Program, National University of Malaysia (UKM), Bangi, Selangor, Malaysia. Email: ibahuda@ukm.edu.my

${ }^{2}$ A postgraduate student (East Asian Studies Program), at the National University of Malaysia (UKM), Bangi, Selangor, Malaysia. Email: P10182@siswa.ukm.edu.my

${ }^{3}$ World Health Organization (WHO), COVID-19 Weekly Epidemiological Update, WHO, 28 February, 2021, available at: https://covid19.who.int/, accessed on 1 March, 2021.

${ }^{4}$ Association of the Southeast Asian Nations (ASEAN), Risk Assessment for International Dissemination of COVID-19 to the ASEAN Region, ASEAN Biodiaspora Virtual Center (ABVC), 4 January, 2021, available at: https://asean.org/storage/COVID-19 Report-of-ASEAN-BioDiaspora-Regional-Virtual-

Center 4January2021.pdf, accessed on 1 March, 2021.
} 
viruses (such as SARS, Ebola, and MERS), its infection rate is uniquely higher and has spread at a faster rate than the previous viruses. ${ }^{5}$ The number of the infected and the death tolls continue to rise, adding up to the existing statistics as more countries breached the 100 thousand cases mark, painting a rather gloomy picture of the virus spread outbreak. The public is anxiously passing each day with the hope of returning to some level of normalcy.

COVID-19 is an unprecedented crisis on a global scale. It reveals the other side of globalization. Globalization can be contextualized as a gradual and ongoing spatial phenomenon due to the expansion of interactive processes, forms of organizations, and forms of cooperation outside sovereign spaces. ${ }^{6}$ Consequently, sovereign boundaries and governance become blurry. The process of globalization does not only expand interstate connections in terms of the flow of goods and capital, but it also increases the interpenetration of people and ideas. Likewise, the higher the human mobility, the higher the rate of virus spread and infections. This explains why states' first responses were to close their national boundaries and restrict border movements, and some states even went to the extreme of putting the whole country under strict lockdown in order to slow down the infection. Border closures were just a knee-jerk short-term solution which were more damaging in the long run.

A global crisis like COVID-19 demands a global solution. States cannot survive in isolation. The history of epidemic control such as with Cholera and SARS had developed a framework of international cooperation. The League of Nations' Health Organization, the predecessor of WHO, was founded in the wake of the Spanish flu during World War I and the spread of Cholera proved that having international convention ${ }^{7}$ without global solidarity alone is not sufficient in the battle against infectious diseases. The COVID-19 pandemic has shown that no state is excluded as the virus ravishes every country in its path, be it a major or middle power. Surprisingly, the major powers have been more devastatingly affected in contrast to smaller powers which seem to be faring well, like ASEAN member states (AMS). WHO early mismanagement of this pandemic is indicative that it does not have adequate institutional power and funding to handle the pandemic, this is also due to its cautious communication and reliance on China. This insufficiency serves as a signal for middle and small powers alike to forgather in an effort to survive and co-exist with the virus in the years to come.

Home to 600 million people, ASEAN must ensure that socioeconomic activities be restored to pre-pandemic levels through a comprehensive and responsive recovery plan and safeguard the resilience and stability of post-pandemic years. It will indeed be challenging for ASEAN to navigate this recovery, but through a combination of regional and international cooperation, there is some prospect that this is taking shape gradually. Thus, this article will attempt to elucidate the impact of COVID-19 in ASEAN and how open regionalism strengthens the solidarity and cooperation between ASEAN and ASEAN Plus Three (APT) partners, especially Japan, in post-COVID-19 recovery.

\footnotetext{
${ }^{5}$ Andrew Pekosz, No, COVID-19 Is Not the Flu, John Hopkins Bloomberg School of Public Health, 20 October, 2020, available at: https://www.jhsph.edu/covid-19/articles/no-covid-19-is-not-the-flu.html, accessed on 1 March, 2021.

${ }^{6}$ Victor D. Cha, “Globalization and the Study of International Security," Journal of Peace Research, Vol. 37, No. 3. 2000, pp. 391-403.

${ }^{7}$ Refers to International Sanitary Conventions 1903, the first convention on epidemic controls convened in Paris. The first framework for international health cooperation. For more information, see https://www.who.int/global_health_histories/background/en/,accessed on 1 March, 2021.
} 


\section{IMPACTS OF COVID-19 IN SOUTHEAST ASIAN STATES}

As mentioned earlier, globalization has facilitated the spread of COVID-19. Due to high transmission rates caused by the high mobility of people across borders and zero herd immunity, the fatality rate is increasing exponentially. The pandemic has not only affected lives, but the livelihood of people as well. In this instance, health and security domains overlap because the spread of the virus is not only considered as a threat to public health concerns alone, but it has rallying impacts on other components of human security: economic, food, environmental, personal, community, and political security. This section will illustrate the devastating impacts of COVID-19 in ASEAN.

\section{Economic Cost of The Pandemic}

The pandemic has paralyzed the global economy. The economic impacts of this influenza are manifested in two forms. The first category includes the direct and indirect economic costs of the illness. The direct cost of the illness can be measured by the resources that are utilized in the treatment of infection. This refers to the cost of stockpiling personal protective equipment (PPE), ventilators, hospital beds and any other resources that would be free for other illnesses if the infection was successfully averted in the first place. WHO estimates 1 out of 20 patients $(5 \%)$ will require intensive care which includes being put on sedatives and ventilators. ${ }^{8}$ Consequently, an annual rough estimate of $0.7 \%$ of global gross domestic product (GDP) is expected to be lost if the pandemic continues to drag on as most of the resources will be concentrated in the treatment of the infected population. ${ }^{9}$ In contrast, the indirect cost involves the resources lost to morbidity and premature mortality. Premature deaths contribute to loss of income generated as a result of reduced sizes of labour and productivity. In ASEAN, the prevalence of non-communicable disease (NCD) is high and is considered as the leading cause of death, accounting for an estimated $62 \%$ ( 8.5 million) of all deaths; approximately $50 \%$ of these deaths occur in people under 70 years of age. ${ }^{10}$ Though it is difficult to quantify this loss, the high premature mortality will contract the national GDP further as the pandemic will increase the prevalence of NCD in the region due to unequal access to food systems (and to some extent, changed lifestyle).

The second category of economic cost is the costs incurred from the transmission control policies implemented by governments in order to flatten the curve of virus transmission and other preventive behaviours adopted by the citizens. When the virus first strikes the region, all AMS immediately embraced stricter policies to curb the spread in the initial stage. Although responses varied, they enforced some level of containment measures such as border closures,

\footnotetext{
${ }^{8}$ World Health Organization (WHO), Statement - Where Do We Stand Today on COVID-19, and What Have We Learned?, WHO, 8 April, 2020, available at: https://www.euro.who.int/en/mediacentre/sections/statements/2020/statement-where-do-we-stand-today-on-covid-19,-and-what-have-we-learned, accessed on 1 March, 2021.

${ }^{9}$ Victoria Y Fan, Dean T Jamison, and Lawrence H Summers, 'The Loss from Pandemic Influenza Risk,' in James D T, Gelband H, Horton S, et al., eds., Disease Control Priorities: Improving Health and Reducing Poverty, 3rd edition, Washington D.C.: The World Bank, 2017, available at: https://www.ncbi.nlm.nih.gov/books/NBK525291/, accessed on 1 March, 2021.

${ }^{10}$ Nina T Castilo-Carandang, Robert D Buenaventura, Yook-Chin Chia, et al., "Moving Towards Optimized NonCommunicable Disease Management in the ASEAN Region: Recommendations from a Review and Multidisciplinary Expert Panel", Risk Manag Health Policy, 2020, available at: https://pubmed.ncbi.nlm.nih.gov/32765135/, accessed on 1 March, 2021.
} 
movement control policies and social distancing requirements in order to avoid contagion and a collapse of the healthcare system. Avoidance costs derived from such suppressive measures far exceeded the direct and indirect cost of illness as has been demonstrated in the outbreak of SARS in 2003. ${ }^{11}$ In the latest ADB report released in November 2020, developing economies in the Southeast Asian region are expected to incur more economic losses compared to East Asian economies (particularly observed in South Korea and Japan) which have been able to contain the virus via aggressive testing, contact tracing, and avoidance of stringent containment measures. Table 1 shows the regional loss estimated for ASEAN+3 economies (relative to noCOVID-19 baseline) based on a 6-month containment period to bring the virus under control. The longer the virus lingers in the region, the more losses will be incurred.

Table 1: Estimated Regional Losses due to COVID-19 (relative to a no- COVID-19 baseline)

\begin{tabular}{|l|c|c|}
\hline & GDP(\%) & GDP(USD billion) \\
\hline ASEAN+3 & $\mathbf{9 . 1}$ & $\mathbf{2 9 4 7 . 0}$ \\
China & 7.6 & 1031.7 \\
Japan & 8.8 & 438.6 \\
South Korea & 6.8 & 109.6 \\
\hline Southeast Asia & 11.1 & 329.4 \\
\hline
\end{tabular}

Source: ADB Staff Estimates (November 2020)

The integration of the ASEAN Economic Community has brought Southeast and Northeast Asian economies closer. In comparison to the SARS outbreak, China is more deeply integrated in the regional economies. The preventive measures taken by the neighbouring states has created a mutually reinforcing economic shock due to disrupted supply and demand from China as well as other partner economies. The COVID-19 pandemic has revealed the vulnerability of trade relations as the virus has hit critical trading nodes which includes China, UK, USA, and Japan. For ASEAN, this is problematic as all these critical nodes are ASEAN main economic partners. In the first quarter of 2020, ASEAN already overtook EU and became China's largest trading partner. ASEAN-China trade amounted to USD140 billion, accounting for 15 percent of China's total trade volume. ${ }^{12}$ Unfortunately, continued heavy reliance on China will have an adverse impact on ASEAN if China faces new outbreaks in the future because AMS are mainly downstream countries in the globalized value chain. The region is currently recovering from the US-China trade tension that has to some extent (diverted trades and investment away and) increased cost of trading caused by protectionist policies. Another disruption in the global supply chain will put more strain on trade as well as investment trends in the region. This is especially true for Vietnam, Cambodia, Singapore, and Malaysia which are susceptible to supply shocks due to their high backward linkages, whereas, high forward countries such as Brunei, Indonesia, Myanmar and Laos are more susceptible to demand shocks. ${ }^{13}$

The immediate impact of containment strategies has been greatly felt in the tourism industry. Within the region, tourism is a major revenue source for many AMS, especially in Thailand (38.3 million), Malaysia (25.8 million), Singapore (18.5 million), Indonesia (15.8

\footnotetext{
${ }^{11}$ World Bank. East Asia and Pacific in the Time of COVID-19: East Asia and Pacific Economic Update - April 2021, World Bank: Washington, DC, 2021, pp. 33-34.

12 Association of the Southeast Asian Nations (ASEAN), ASEAN Overtakes EU to Become China's Top Trading Partner in Q1, 15 May, 2020. Available at: https://www.aseanbriefing.com/news/asean-overtakes-eu-becomechinas-top-trading-partner-q1-2020/, accessed on 1 March, 2021.

${ }^{13}$ World Bank. East Asia and Pacific in the Time of COVID-19: East Asia and Pacific Economic Update - April 2021, p. 76.
} 
million), and Viet Nam (15.5 million), in which intra-ASEAN visitors made up 49.7 million or $36.7 \%$ of the overall 135.3 million visitor arrivals to ASEAN in 2018. ${ }^{14}$ Given that reduced tourism demands are necessary for virus containment, massive labour lay-off is also taking place in tourism-related industries such as aviation and hospitality, adding to the already existing high economic costs. Although the region has shown resilience in weathering the first wave, the same is inconceivable for countries which are currently experiencing second or even third waves of outbreaks.

It will be increasingly difficult to revive the international tourism industry as new cycles of waves begin, and also partly due to the emergence of a new variant detected in the United Kingdom. The UK variant has a large number of mutations which seem to spread faster (with $70 \%$ transmissibility rate) and infects the younger population (below 70 years old) in contrast to previous variants ${ }^{15}$. Several sequencing genome research in the UK has demonstrated that the variant is responsible for the recent surge of cases (more than 3000) in Southern East England and this sparks fear that the national healthcare system will be overburdened by increased illness and hospitalization once the variant gains in any of the regions. ${ }^{16}$ At the time of this research compilation, Australia, Japan, South Korea, Singapore, Hong Kong, and Malaysia detected their first confirmed cases of the UK variant, pushing these countries to consider re-imposing stricter travel restriction and entry bans for UK arrivals.

\section{Socioeconomic Costs of The Pandemic}

The impact of the economic fallout from COVID-19 has been devastating to the social wellbeing of the people. As mentioned earlier, the halt on international travel has led to mass layoffs in aviation, tourism and hospitality industries. These layoffs however do not stop at the tourism-related industries. Although at present there is no data available on the full-scale unemployment increase in the region, prospects remain bleak. Service, labour-intensive and supply-chain based manufacturing industries comprise more than 80 percent of the region's informal sector and small and medium enterprises (SMEs); these areas contribute to most of the jobs in the region and have been among the hardest hit by the virus outbreaks. ${ }^{17}$ SMEs will bear the brunt of the recession and have to undergo major restructuring, i.e retrenchment, in order to cut operational costs. As a result, approximately 54 million people will be forced into

14 The ASEAN Secretariat, ASEAN Key Figures 2019, ASEAN, 15 October, 2019, available at: https://www.aseanstats.org/wp-content/uploads/2019/11/ASEAN_Key_Figures_2019.pdf, accessed on 1 March, 2021.

${ }^{15}$ Centers for Disease Control and Prevention (CDC), About Variants of the Virus that Causes COCID-19, CDC, 12 February, 2021, available at: https://www.cdc.gov/coronavirus/2019ncov/transmission/variant.html\#: :text=Multiple\%20COVID\%2D19\%20variants\%20are,or\%20increased\%20ri sk\%20of\%20death, accessed on 1 March, 2021.

${ }^{16}$ World Health Organization (WHO), SARS-CoV-2 Variant - United Kingdom of Great Britain and Northern Ireland, WHO, 21 December, 2020, available at: https://www.who.int/csr/don/21-december-2020-sars-cov2variant-united-kingdom/en/, accessed on 1 March, 2021; James Gallagher, New Coronavirus Variant: What Do We Know? BBC, 20 December 2020, available at: https://www.bbc.com/news/health-55388846, accessed on 1 March, 2021; Melissa Healy, New Evidence that U.K. Coronavirus Variant Spreads More Easily has Scientists Really Worried, Los Angeles Times, 10 January, 2021, available at: https://www.latimes.com/science/story/202101-10/new-evidence-that-u-k-coronavirus-variant-spreads-more-easily-has-scientists-really-worried, accessed on $1 \mathrm{March}, 2021$.

${ }^{17}$ United Nations Economic and Social Commission for Asia and the Pacific (UNESCAP), The Impact and Policy Responses for COVID-19 in Asia and the Pacific. United Nations, July 2020, available at: https://www.unescap.org/sites/default/d8files/knowledge-products/COVID\%20_Report_ESCAP.pdf, accessed on 1 March, 2021. 
poverty. ${ }^{18}$ The creation of new pockets of poverty will undo the progress of poverty alleviation in the region.

Within the region, the gig economy has been witnessing a rising upward trend due to Southeast Asia strategic positioning as a key market based on two preconditions; 1) the population transition is still not completed, and 2) working age populations with high internet literacy made up a large portion of the population. ${ }^{19}$ This boosts the region's attractiveness for the gig economy to thrive in as more start-ups prefer to hire freelancers and contractors for short-term projects. Unfortunately, the pandemic has put those working in the gig economy under threat given that the majority do not have the social and financial security net as compared to traditional full-time employees. With no social insurance (health coverage, pension or employment provident funds), they are more vulnerable to health risks due to limited access to healthcare.

Social isolation stemming from containment measures is also threatening the region's progress in achieving quality education for its population. Containment measures challenge traditional education practices as educational institutions have to shift their operation to virtual platforms. Due to the wide digital divide among and within ASEAN member states, more than 152 million children and youths may have been affected by school and university closures. ${ }^{20}$ Excluding Singapore, the rest are not particularly ready for this sudden shift. The situation is even more pressing in Cambodia, Laos, Myanmar, and Philippines due to a lack of access to social security nets, electricity, and the fact that the majority of the population falls between the cracks of governments' social welfare supports. ${ }^{21}$ The limited access to resources, supports, and infrastructure will contribute to lost years of learning. This in turn will lead to human capital loss because learning and training will shape the workforces of the region. If the current systems are not able to address the widening gap and lost years of learning in the immediate future, the region's aspirations to fill the growing need for a high-skilled labour force won't be achieved. Hence, growth and integration will also be at risk and will further contribute to vicious cycles of poverty.

Furthermore, school closures have also complicated ASEAN's efforts in addressing the double burden of malnutrition. A joint report from the United Nation Children's Fund (UNICEF) and WHO in 2019 revealed that AMS are facing simultaneous crises of over and undernutrition, with some children overweight while their peers suffer from stunting and wasting. These crises are more prevalent in middle-income countries, especially Indonesia, Thailand, Malaysia, and Philippines. To address this, ASEAN governments have been implementing food assistance programs for children in schools to ensure they receive adequate nutrients and reduce the costs of lost productivity stemming from it. However, these children no longer receive nutrient assistance since school closures began and therefore, their nutritional progress is at risk. This will lead to a higher prevalence of obesity, stunting and NCD among children.

Apart from the lives lost to the virus, ASEAN is also witnessing an alarming upward trend of suicides in its population. Economic fallout, social isolation, and pre-existing mental health issues are among the causes identified. WHO data on suicide rate ranks Thailand as

\footnotetext{
18 The ASEAN Secretariat, ASEAN Rapid Assessment: The Impact of COVID-19 on Livelihoods Across ASEAN, Jakarta: The ASEAN Secretariat, 23 November, 2020, pp. 20-32, available at: https://asean.org/storage/ASEANRapid-Assessment_Final-23112020.pdf, accessed on 1 March, 2021.

19 PayPal, PayPal Global Freelancer Survey, PayPal, 1 March, 2018, available at: https://www.paypal.com/stories/sea/paypal-global-freelancer-survey, accessed on 1 March, 2021.

20 The ASEAN Secretariat, ASEAN Rapid Assessment: The Impact of COVID-19 on Livelihoods Across ASEAN, Jakarta: The ASEAN Secretariat, 23 November, 2020, pp. 47-56, available at: https://asean.org/storage/ASEANRapid-Assessment_Final-23112020.pdf, accessed on 1 March, 2021.

${ }^{21}$ The ASEAN Secretariat, ASEAN Rapid Assessment: The Impact of COVID-19 on Livelihoods Across ASEAN, Ibid. p. 59.
} 
having the highest annual suicide rate in Southeast Asia, with 14.4 suicides for every 100,000 population, equivalent to 10,000 deaths by suicide per year. ${ }^{22}$ At the end of April 2020, Thailand recorded 28 suicides $^{23}$ while Malaysia reported 78 suicides since the movement restriction order was imposed nationwide. ${ }^{24}$ The same issue is also present in other AMS as helplines recorded increasing numbers of distressed calls with suicidal intents. As the virus progresses, it will exert more mental pressure on the public to cope with the anxiety of coexisting with the virus as well as adjusting themselves to the new normal. Unfortunate as it is, more lives will be lost to suicides than to the virus itself if the socioeconomic impacts of the virus are not addressed properly by the ASEAN governments.

\section{OPEN REGIONALISM: KEY TO POST COVID-19 RECOVERY}

Indeed, the COVID-19 pandemic is an unprecedented global health crisis, but the challenges and impacts that come with it are not foreign to us. A virus outbreak, economic crisis, global recession the region already faced these crises before, albeit on a smaller scale. What makes COVID-19 recovery a bumpy road is because all these 'shocks' are happening simultaneously everywhere and at a much faster speed compared to the previous crises. The answer to a post COVID-19 recovery has been obvious from the moment the outbreak started. No country can come out of this crisis alone. ASEAN realized this early on after receiving criticism about its lack of regional response in the initial stage of the virus containment. Globally, while countries continue to focus inward on their responses towards COVID-19 recovery, ASEAN regional responses are worthy of recognition, though less of a spotlight has been given to it. Despite diverse national policies to contain the virus locally, ASEAN has been working hand in hand with its partners (either bilaterally or multilaterally) in an attempt to reopen borders and reinvigorate global supply chains. Hence, ASEAN regionalism has become more 'open' as demonstrated through increased health and economic cooperation with APT members, especially Japan, which is significant to post Covid-19 recovery.

Taking into account their experience in facing SARS in 2003, as a regional body, ASEAN swiftly responded to the new unknown pneumonia outbreak that started in a Wuhan seafood market. Given the immeasurable gap in knowledge and the information on how to appropriately and effectively prevent, detect, and respond to the spread of the disease, ASEAN Health Division immediately activated and mobilized the regional mechanisms with ASEAN Plus Three (APT) countries: China, Republic of Korea (ROK), and Japan. Among the mechanisms activated under the ambit of ASEAN Health Division are: (i) ASEAN Senior Officials Meeting for Health Development (SOMHD), (ii) ASEAN APT SOMHD, (iii) ASEAN and ASEAN Plus Three Corresponding Health Minister Platforms, and (iv) ASEAN Health Cluster on Responding to all Hazards and Emerging Threats. ${ }^{25}$ These mechanisms are responsible in providing support to ASEAN Emergency Operation Centre (ASEAN EOC) led by Malaysia as the host country. Through the numerous video conferences convened, ASEAN and its dialogue partners (such as Italy, France, United States, European Union and APT

\footnotetext{
22 Ana Salva, Thailand: The Coronavirus Suicides, The Diplomat, 11 May, 2020, available at: https://thediplomat.com/2020/05/thailand-the-coronavirus-suicides/, accessed on 1 March, 2021.

${ }^{23}$ Ibid.

${ }^{24}$ Hazlin Hassan, COVID-19 Crisis Taking a Toll on Malaysians' Mental Health, The Straits Times, 27 July, 2020, available at: https://www.straitstimes.com/asia/se-asia/covid-19-crisis-taking-a-toll-on-malaysians-mentalhealth, accessed on 1 March, 2021.

${ }^{25}$ Ferdinal M. Fernando, Jennifer Frances E. De La Rosa, and Mary Kathleen Quiano-Castro, COVID-19: A Collective Response in ASEAN, The ASEAN Magazine, 1 May, 2020, available at: https://asean.org/storage/2017/09/The-ASEAN-Magazine-Issue-1-May-2020.pdf, accessed on 1 March, 2021.
} 
members) have been sharing their experiences handling the virus and reaffirmation of commitment on cooperation for a post COVID-19 recovery.

Under the framework of APT, the cooperation of AMS with each APT member also heightened amidst the pandemic. All member states recognized that synchronized responses at the regional and global level are required; hence, coordination is of the utmost importance in this battle. The Joint Statement of the Special ASEAN Plus Three Summit on coronavirus disease 2019 (COVID-19) on April 19, 2020, reiterated the spirit of a 'Cohesive and Responsive' ASEAN and demonstrates its highest level of commitment to a collective response against the virus. It also emphasizes the significance and contribution of various ASEAN Health Sector mechanisms as well as the importance of adequate funding to contain the virus and protect the livelihoods of the people which led to the establishment of the COVID-19 ASEAN Response Fund for public health emergencies.

Proposed by Thailand, the fund will be reallocated from two sources: (i) ASEAN Development Fund and (ii) cooperation fund from developing partners. $10 \%$ will be pooled from each fund to procure medical equipment as well as for research and development of a vaccine, test kits, and antiviral drugs. With an initial target of USD 3 billion, the APT Cooperation Fund launched in 2003 has pooled contributions amounting to USD 1.2 billion (USD 900 million from APT and USD 300 million from AMS). ${ }^{26}$ Both ROK ${ }^{27}$ and Japan have pledged to contribute USD 1 million to the fund. ${ }^{28}$ The framework for the fund is also extended from ASEAN+1 to include external partners such as the US which contributed USD 87 million to the Southeast Asian region that will be utilized for the training of medical workers, boosting screening capabilities and national health systems. ${ }^{29}$ In like manner, ASEAN is also developing ASEAN Regional Reserve of Medical Supplies for Public Health Emergencies and ASEAN Strategic Framework for Public Health Emergencies in order to enhance the region's preparedness in responding to future pandemic and health emergencies.

With the support from the government of Japan, ASEAN Secretariat and Ministry of Health from Malaysia and Vietnam conducted a study to access the feasibility of establishing ASEAN Center for Public Health Emergencies and Emerging Diseases (ACPHEED). ACPHEED will serve as an institution to strengthen the functions of national public health agencies and promote public health and safety through control and prevention of disease, injury and disability at the regional level. ${ }^{30}$ Based on the findings from the feasibility study, both parties have agreed and announced the establishment of the Centre once a host country has been selected in the region. Japan has pledged its full support to ACPHEED through its 50 million USD contribution to the Japan-ASEAN Integration Fund (JAIF) for the establishment

\footnotetext{
${ }^{26}$ Dian Septiari, Leaders Support the Establishment of Covid-19 Response Fund, The Jakarta Post, 14 April 2020, available at: https://www.thejakartapost.com/seasia/2020/04/14/leaders-support-establishment-of-aseancovid-19-response-fund.html, accessed on 1 March, 2021.

${ }^{27}$ Ministry of Foreign Affairs, Senior Officials' Meetings of APT, EAS and ARF Take Place. Republic of Korea's Ministry of Foreign Affairs, 23 July, 2020, available at:

http://www.mofa.go.kr/eng/brd/m_5676/view.do?seq=321169\&srchFr=\&amp;srchTo=\&amp;srchWord=\&amp; srchTp=\&amp;multi_itm_seq=0\&amp;itm_seq_1=0\&amp;itm_seq_2=0\&amp;company_cd=\&amp;company_n $\underline{m}=\&$ page $=1 \&$ titleNm $=$, accessed on 1 March, 2021.

${ }^{28}$ Ministry of Foreign Affairs of Japan, 23rd Japan-ASEAN Summit Meeting, Ministry of Foreign Affairs of Japan, 12 November, 2020, available at: https://www.mofa.go.jp/a_o/rp/page3e_001075.html,accessed on 1 March, 2021.

${ }^{29}$ Center for Strategic \& International Studies (CSIS), Southeast Asia COVID-19 Tracker, CSIS, March 2021, available at: https://www.csis.org/programs/southeast-asia-program/southeast-asia-covid-19-tracker-0, accessed on 1 March, 2021.

${ }^{30}$ Japan-ASEAN Integrated Fund (JAIF), A Feasibility Study on the Establishment of "ASEAN Centre for Public Health Emergencies and Emerging Diseases”, JAIF, 31 August, 2020, available at: https://jaif.asean.org/project-brief/a-feasibility-study-on-the-establishment-of-asean-centre-for-public-healthemergencies-and-emerging-diseases/, accessed on 1 March, 2021.
} 
of the Centre. In addition, Japan through Japan International Cooperation Agency (JICA) will also provide technical assistance as well as human resources development by training and dispatching experts for continuous knowledge and expertise exchanges.

At the same time, Japan is also actively pursuing government-to-government cooperation with ASEAN governments. Among the assistance provided are Exchange of Notes for medical equipment provisions, low-interest loans, donation of PPE and delivery of Avigan to four AMS (Philippines, Malaysia, Indonesia and Myanmar) for clinical trials ${ }^{31}$ as can be summarized in Table 2:

\section{Table 2: Japan's Assistance to ASEAN Member States}

\begin{tabular}{|c|c|}
\hline Country & Financial (JPY) and medical assistance \\
\hline Indonesia & $\begin{array}{l}\text { - Offered } 50 \text { billion in low-interest loan, in addition to } 32 \text { billion contributed in Feb } 2020 . \\
\text { - Delivered 12,2000 Avigan tablets, } 5 \text { ventilators through partnership with WHO and will } \\
\text { contribute another } 25 \text { ventilators. }\end{array}$ \\
\hline Malaysia & $\begin{array}{l}\text { - } 500 \text { million aid grant of medical equipment provision to enhance preparedness and } \\
\text { response capacity of Ministry of Health. } \\
2 \text { million (USD) worth of food, PPEs, medical vehicles and ICT equipment for online } \\
\text { education contributed through IFRC, UNICEF and UNHCR in Malaysia, to help alleviate } \\
\text { the difficulties of the socially vulnerable people in Malaysia. }\end{array}$ \\
\hline Philippines & $\begin{array}{l}\text { - } 2 \text { billion grant aid and an addition of a } 50 \text { billion loan payable in } 15 \text { years, with a } 4 \text {-year } \\
\text { grace period for COVID-19 Crisis Emergency Support. }\end{array}$ \\
\hline Vietnam & $\begin{array}{l}\text { - } 2 \text { billion aid grant for technical upgrading of } 4 \text { core hospitals in Vietnam (1.8 billion for } \\
\text { the Vietnamese government and about } 200 \text { million for the agents designated by the } \\
\text { Japanese government) } \\
\text { JICA provided } 14 \text { million worth of rapid reagent test kits to National Institute of Hygiene } \\
\text { and Epidemiology }\end{array}$ \\
\hline Laos & $\begin{array}{l}\text { - } 1.5 \text { billion aid grant for medical equipment provision. } \\
\text { - Donated 4,680 isolation gowns, 6,100 gloves, 6,000 N95 face masks, 13,200 surgical } \\
\text { gowns, } 27 \text { goggles, and } 240 \text { bottles of hand-rub alcohol to Laos. }\end{array}$ \\
\hline Myanmar & $\begin{array}{l}\text { - } 2 \text { billion aid grant for medical equipment provision. } \\
\text { - Pledged to provide } 30 \text { billion in loans for emergency budget support and } 15 \text { billion to } \\
\text { assist small and medium-sized enterprises. } \\
\text { - JICA pledged to provide } 400,000 \text { worth of primer and testing reagents to National Health } \\
\text { Laboratory of Myanmar for rapid detection. }\end{array}$ \\
\hline Cambodia & $\begin{array}{l}\text { - Extended } 6 \text { million USD (approx. JPY632 million) worth of medical supplies and } \\
\text { technical assistance through the United Nations Office for Project Services }\end{array}$ \\
\hline
\end{tabular}

Sources: Compiled from Ministry of Foreign Affairs of AMS and various newspapers articles (Jan 2020 - Jan $2021)^{32}$

ASEAN and Japan also have an impending battle against vaccine nationalism. In the recently convened World Economic Forum's Davos Agenda 2021, both foreign ministers from Japan and ROK expressed their worry over EU's threat of a vaccine embargo. The worry was caused by the growing nationalism which may block export of those vaccines to third world countries in order to secure sufficient amounts for the European population first. During the panel, Kono Taro and Kang Kyung Hwa called on the international cooperation against

\footnotetext{
${ }^{31}$ Four ASEAN nations among 38 to get Avigan drug from Japan for clinical trial, The Star, 29 April 2020, available at: https://www.thestar.com.my/news/regional/2020/04/29/four-asean-nations-among-38-to-getavigan-drug-from-japan-for-clinical-trial, accessed on 1 March, 2021.

32 Japan International Cooperation Agency (JICA), Emergency Assistance to Counter with Coronavirus in Myanmar - Providing a Primer (Testing Kit) to the National Health Laboratory (NHL.), JICA, 25 February 2020, available at: https://www.jica.go.jp/myanmar/english/office/topics/press200225.html, accessed on 1 March, 2021.
} 
adopting export control on a vaccine. That is precisely why Japan has been actively involved in COVAX facility, co-led by WHO and Gavi, the Vaccine Alliance. On Sept 16 2020, the Japanese government pledged 130 million USD to Gavi COVAX Advance Market Commitment (AMC), bringing the fund closer to its target of 2 billion USD before the end of $2020 .{ }^{33}$ Other AMS such as Singapore and Malaysia have also joined COVAX. With Japan and other AMS commitment to support the COVAX facility, it will help accelerate equitable access and distribution of vaccines to lower- and middle-income countries.

Apart from health cooperation, the path to recovery will demand APT to strengthen regional cooperation and integration (RCI) more now than ever. RCI will enable the region to bounce back from the pandemic stronger than before. The pandemic has revealed the vulnerabilities of ASEAN economies against global shock as well as its unsustainable development when facing the pandemic individually. Given that the development gaps in the region are too wide to be accounted for, the socio-economic impacts of the pandemic across the member states have been varied, with the more well-developed economies (especially Vietnam and Singapore) surviving fairly well while the less-developed are struggling to cope with the virus. In order to reduce vulnerabilities against health emergencies and economic shocks, it is imperative for ASEAN to become more integrated in its trade, investments, infrastructure, and financial networks.

\section{RECOMMENDATIONS FOR CLOSER COOPERATION}

Firstly, ASEAN should strive to maintain a resilient supply chain within the region and with its partners. As discussed earlier, ASEAN overdependence on China has caused a shock in its supply chain. This disruption has instead spurred a drive centred on domestic production of critical medical supplies such as masks and PPE in Vietnam. In order to counter shortages of materials from China, Vietnam has been increasing local procurement rates by attracting inbound investment and nurturing local enterprises, including the development of the Ran Dong Textile Industrial Park. ${ }^{34}$ Through a research and development cooperation with the US's Massachusetts Institute of Technology and Medtronic (a major medical equipment manufacturer), Vietnam has successfully manufactured its own ventilator and has received distribution approval from its ministry of health in June 2020. Vietnam's success in developing its own domestic production of medical supplies has inspired Indonesia, Thailand, and Malaysia to attract inbound investments as well. While establishing domestic production may cushion the shock temporarily, it still does not address the overall vulnerability of the supply chain.

What AMS can do instead is to push forward the digitalization of its supply chain. Digitalization can help reduce logistic issues stemming from external shocks such as climacticinduced disasters and virus outbreaks. The internet of things, big data analysis, algorithm-based analytics, artificial intelligence, augmentation and automation employing new technologies will improve connectivity and speed up RCI as barriers to production and distribution will be significantly reduced through digitalization. ASEAN already has several mechanisms which can accelerate and facilitate trade such as the ASEAN Single Window (ASW). ASW enables a

\footnotetext{
33 The Vaccine Alliance (GAVI), Japan Pledges USD 130 million to Support Global Access to COVID-19 Vaccines, GAVI, 12 April, 2020, available at: https://www.gavi.org/news/media-room/japan-pledges-us-130million-support-global-access-covid-19-vaccines, accessed on 1 March, 2021.

${ }^{34}$ Yuki Fukuoka, Supply Chain Transformation Underway in Southeast Asia - Production Shift Due to Us-China Conflict and Strengthened Resilience in Response to the Covid-19 Pandemic, Mitsui \& Co. Global Strategic Studies Institute, 18 September, 2020, available at: https://www.mitsui.com/mgssi/en/report/detail/_ icsFiles/afieldfile/2020/09/18/2008c fukuoka_e.pdf, accessed on 1 March, 2021.
} 
seamless exchange of trade-related documents (customs declarations, certificates of origin and sanitary and phytosanitary certificates) digitally. The pandemic has highlighted the need for ASEAN to enlarge the aperture to ASEAN-Plus Single Window, particularly with the inclusion of Japan, ROK, New Zealand, Australia and China which have more experiences in crossborder paperless trade. ${ }^{35}$ Together, a proper framework can be designed that will help speed up cross-data checking between agencies. In addition, this region is also a battlefield for global digital competition for its market attractiveness and ease of doing business. Banking on these premises, APT will benefit more by investing in the digitalization of its supply chain which in turn improves its value chain as well.

From 18-21 Jan 2021, Malaysia headed the virtual inaugural of ASEAN Digital Ministers' Meeting (ADGMIN1), joined by dialogue partners from the United States, China, Japan, South Korea, India, the European Union (EU) and the International Telecommunication Union (ITU). ASEAN successfully adopted the ASEAN Digital Masterplan 2025 (ADM2025), endorsed and adopted the Putrajaya Declaration on "ASEAN a Digitally Connected Community" in its concerted efforts to lay the groundwork for reshaping ASEAN's postCOVID-19 digital landscape. According to Vietnam's ambassador to Malaysia, Dr. Tran Viet Thai, ASEAN countries are well-placed and well prepared to accelerate the growth of a digital economy, as well as having good political will and a well-designed masterplan for digitalization. ${ }^{36}$ The digital economy is seen as the next driver of growth given that the region is home to an estimated 400 million internet users coupled with the unexpected boom in digital commerce amidst the pandemic.

To address the issue of heavy reliance on China, Japan has recently released a trade white paper in July 2020 which expressed the same worry. A senior official at the Ministry of Economy, Trade and Industry (METI) told The Straits Times that the region must construct a system that is robust by locating the choke-points and procuring materials from many countries, as well as diversification of supply chains to enhance food and energy security. In the white paper, Japan offered a subsidy scheme worth 2.3 billion JPY for Japanese companies to either re-shore to their homeland or to relocate to any ASEAN countries. ${ }^{37}$ Under the scheme, the Japanese government will cover half of the cost of investment within ASEAN for both large and small firms. Previously, Japan has also allocated 23.5 billion JPY to help firms move production to Southeast Asia in which the government has already approved 30 projects in the first round of applications as of the end of June. Half of the firms applied targeted Vietnam (and Indonesia) to set up their production bases due to low averages of annual wages for manufacturing workers. On the issue of digitalization, Japan will also increase its investment and work closely with ASEAN to promote a rule-based trade in the digital sphere. This is in line with Japan's Osaka Track launched during the G20 summit 2019, establishing a framework for digital data flow with trust among the governments and businesses across borders.

Secondly, the ASEAN market should remain open to ensure the smooth flow of trade, services, and investments. Amidst the pandemic, ASEAN and Japan have made some remarkable developments via economic partnerships. The First Protocol to Amend the Agreement on Comprehensive Economic Partnership among Japan and ASEAN (AJCEP) has

\footnotetext{
${ }^{35}$ Sithanonxay Suvannaphakdy, ASEAN Single Window: Time to Enlarge the Aperture, Yusof Ishak Institute of Southeast Asian Studies (ISEAS), 17 July, 2020, available at: https://www.iseas.edu.sg/media/commentaries/asean-single-window-time-to-enlarge-the-aperture/, accessed on 1 March, 2021.

${ }^{36}$ ASEAN Well Prepared to Accelerate Growth of Digital Economy, Says Vietnam, The Star, 19 January 2021, available at: https://www.thestar.com.my/aseanplus/aseanplus-news/2021/01/19/asean-well-prepared-toaccelerate-growth-of-digital-economy-says-vietnam, accessed on 1 March, 2021.

37 AFM Editorial Office, Japan's efforts to Diversify Supply Chains. Asia Fund Manager (AFM), 28 October 2020, available at: https://www.asiafundmanagers.com/int/japan-supply-chains-diversification/, accessed on 1 March, 2021.
} 
been entered into force on August 1, and both the conclusion of Regional Comprehensive Economic Partnership (RCEP) Agreement as well as the Adoption of ASEAN-Japan Economic Resilience Action Plan in November 2020. As Japan has relocated its production based in ASEAN, both are committed in reducing tariff and non-tariff measures to facilitate trades and investment. These initiatives will help in strengthening the regional economic architecture as APT is the core of RCEP which account for $30 \%$ of global GDP. Closer economic cooperation is therefore essential for sustainable and inclusive growth of the region. In addition to trade agreements inked between Japan and ASEAN, Japan has also created a limited travel bubble with APT member countries for smooth business travels and foreign residence, which will be resumed once the travel ban (January 14 to February 7, 2021) is lifted. ${ }^{38}$

On November 2020, Japan also further emphasizes its support in narrowing the development gaps and facilitate the integration of the ASEAN community. Based on Master Plan on ASEAN Connectivity 2025 and Ayeyawady-Chao Phraya-Mekong Economic Cooperation Strategy (ACMECS) Masterplan, Japan will continue to support the ongoing 2 trillion JPY hard and soft infrastructure development under the 'Japan-ASEAN Connectivity Initiative' over the next three years. ${ }^{39}$ The biggest hard infrastructure projects are the East-West Corridor and Southern Corridor connecting roads in Vietnam and Cambodia, meanwhile other land corridor projects include mass rapid transit constructions in Philippines, Indonesia, Thailand, Myanmar. On the other hand, the air and sea corridor cover port development projects in Cambodia, Myanmar and Indonesia. All three-corridor connectivity projects will be complemented by technical cooperation projects to promote people-to-people relations through capacity building projects for 1000 individuals. This ASEAN-Japan Connectivity Initiative was first announced during the 22nd ASEAN-Japan Summit on Connectivity in 2019 which encourages quality infrastructure development in line with international standards including openness, transparency, economic efficiency in view of lifecycle cost and debt sustainability. ${ }^{40}$

Thirdly, learning from their experience in the Asian Financial Crisis of 1997/98, ASEAN should improve their financial security network. In order to avoid country insolvency due to rising national debt caused by large and unsustainable fiscal responses to COVID-19, ASEAN should foster the usage of its own domestic local currency. AMS could support one another by sourcing domestic currencies to settle bilateral trade investment and transaction and thus, reducing its overdependence on US dollars. This can be done by reactivating the Japanled Chiang Mai Initiative Multilateralized (CMIM) for better regional financial cooperation in response towards future uncertainties. Although the ASEAN Swap Arrangement (ASA) and Bilateral Swap Arrangement (BSA) with the APT partners is seen to be more symbolic than practical due to the arguably small amount of money available for each country to draw from the swap arrangement compared to the actual scale of the financial crisis, it is still a feasible initiative in establishing a liquidity support mechanism for the region.

In contrast, ASEAN governments could also leverage Japan's huge market capitals with Tokyo so that they can be utilized to finance infrastructure investments through governmentbacked bonds. For instance, the Indonesian government raised USD 930 million on $3^{\text {rd }}$ July 2020 through the issuance of five-tranche Samurai bonds in order to finance Indonesia's budget

\footnotetext{
${ }^{38}$ Carey Finn, Japan's Travel Bubble: What Is It, and Who's Included? Tokyo Cheapo, 21 March, 2021, available at: https://tokyocheapo.com/travel/japan-travel-bubbles/, accessed on 26 March, 2021.

${ }_{39}$ Ministry of Foreign Affairs of Japan (MOFA), Japan-ASEAN Connectivity Initiative, MOFA, 2020, available at: https://www.mofa.go.jp/files/100114591.pdf, accessed on 1 March, 2021.

40 Association of the Southeast Asian Nations (ASEAN), Chairman's Statement of the 23rd ASEAN-Japan Summit, ASEAN, 12 November, 2020, available at: https://www.asean2020.vn/documents/225899/226554/20201124000622.342.pdf/53d283c1-6bb0-4b57-8d7f6da043f4dc26, accessed on 1 March, 2021.
} 
deficit, including COVID-19 relief and recovery efforts. ${ }^{41}$ While Japanese Samurai bond market is an attractive alternative source of financing due to its low-interest loans, ASEAN governments should caution against holding large foreign currency debt which could increase the risk of sudden reversal in capital flows. Japan (through JICA), as a strategic partner as well as the largest donor in the region, could help by continuously supporting capacity development in strengthening AMS debt-management practices in order to avoid debt crises. Continuous technical cooperation, know-how exchanges and specialized trainings between ASEAN and Japan on debt sustainability are therefore imperative.

Finally, an ASEAN recovery plan should accord more emphasis on the social dimension of the pandemic. While the fiscal policies help in cushioning the economic impacts, a robust social security framework needs to be in place to assure the public, especially those who fall between the cracks of the social security nets. As discussed in the previous section, the pandemic has affected the region's progress in poverty alleviation, attaining quality education and food security, and most importantly, safeguarding lives. This has shown that there are loopholes in ASEAN social security networks that need to be strengthened in order to reduce insecurities and vulnerabilities to external shocks. The massive outbreaks in Singapore and Malaysia involving thousands of migrant workers reveal that poor working conditions increase their vulnerability to infection and spread of the virus.

The coordination of cross-sectoral ASEAN bodies across pillar and stakeholders in social welfare, labor, health, education, and immigration are required to ensure that the recovery plan is inclusive of the vulnerable and poor population as well as the often marginalized immigrant workers. In this context, Japan could cooperate with ASEAN member states such as Thailand, Malaysia and Indonesia, which are already working on national action plans in Business-Human Rights nexus and well-established human rights institutions installed in most ASEAN states, with the aim to improve the human rights status in the region. Simultaneously, AMS could learn from Japan on how to provide a universal healthcare system, inclusive social security networks while managing high national debts that stem from COVID19. The implementation of a social security framework should also be streamlined with the implementation of Sendai Framework for Disaster Risks Reduction, which emphasizes investment in preventative disaster measures in order to reduce the likelihood of zoonotic infections and the impacts and socio-economic costs of the disasters. ${ }^{42}$

\section{CONCLUSION}

As the pandemic continues to loom over the region and affects lives along its path, international cooperation, especially regionally coordinated responses would be at the forefront of the recovery period of the post COVID-19 pandemic. The adoption of ASEAN Comprehensive Recovery Framework and Implementation Plan at the ASEAN 37 th ASEAN Summit is a promising start that signifies ASEAN and its partners' collective and long-term recovery strategy. With five broad strategies outlined, ASEAN pledged to continuously invest in its people and embrace a whole-of community approach in shaping the new normal. Effective implementation of the framework is something to be looked forward to in 2021 and beyond as

\footnotetext{
${ }^{41}$ Adrian Wail Akhlas, Indonesia Raises USD 930 Million in Samurai Bonds to Fund Pandemic Response, The Jakarta Post, 3 July, 2020, available at: https://www.thejakartapost.com/news/2020/07/03/indonesia-raises930m-in-samurai-bonds-to-fund-pandemic-response.html, accessed on 1 March, 2021.

${ }^{42}$ United Nations Office for Disaster Risk Reduction (UNDRR), General Assembly puts the Sendai Framework at the Centre of COVID-19 Response and Recovery Policy, UNDRR, 21 September, 2020, available at: https://www.undrr.org/news/general-assembly-puts-sendai-framework-centre-covid-19-response-and-recoverypolicy, accessed on 1 March, 2021.
} 
the regional body prepares its citizenry to be more secure, productive, and flexible in facing future uncertainties. The smooth streamlining of the recovery plan will however depend on the success of the ASEAN community in battling the pandemic by ensuring the population is better protected against it through nationwide vaccination programmes in all AMS.

At the same time, as the traditional security provider in the region, Japan will be expected to demonstrate its leadership in the advancement of human security and economic integration in the region. Therefore, a true partnership based on a relationship of mutual trust and equal footing is required to deepen the solidarity and cooperation between ASEAN and Japan in the future, not just in economic affairs but in protecting liberal values and human rights which are witnessing a worrying trend of regression due to the impacts of COVID-19. While some may argue that Japan's diplomacy (assistance) is deeply tied to its economic ambitions in the rapidly growing region, ASEAN Outlook on The Indo-Pacific shares a lot of commonalities with Japan's Free and Open Indo-Pacific which promotes freedom of navigation, rule of laws, openness and inclusivity among others. Thus, there is a bottomless avenue for cooperation for ASEAN and Japan. For a greener development and sustainable growth of the region, both ASEAN and Japan need to forge closer relations and bridge the gaps or mismatches in the policymaking of ASEAN and Japan towards achieving the common goal. The pandemic has granted a level playing field for all nations to work hand-in-hand against the virus. We are vulnerable in the face of the virus and that is exactly why every informed decision and political will accrued will make a huge impact in the post- COVID-19 recovery journey.

\section{REFERENCES}

Adrian Wail Akhlas, Indonesia Raises USD 930 Million in Samurai Bonds to Fund Pandemic Response, The Jakarta Post, 3 July, 2020, available at: https://www.thejakartapost.com/news/2020/07/03/indonesia-raises-930m-in-samurai-bondsto-fund-pandemic-response.html, accessed on 1 March, 2021.

AFM Editorial Office, Japan's efforts to Diversify Supply Chains. Asia Fund Manager (AFM), 28 October 2020, available at: https://www.asiafundmanagers.com/int/japan-supply-chainsdiversification/, accessed on 1 March, 2021.

Ana Salva, Thailand: The Coronavirus Suicides, The Diplomat, 11 May, 2020, available at: https://thediplomat.com/2020/05/thailand-the-coronavirus-suicides/, accessed on $1 \mathrm{March}$, 2021.

Andrew Pekosz, No, COVID-19 Is Not the Flu, John Hopkins Bloomberg School of Public Health, 20 October, 2020, available at: https://www.jhsph.edu/covid-19/articles/no-covid-19is-not-the-flu.html, accessed on 1 March, 2021.

ASEAN Well Prepared to Accelerate Growth of Digital Economy, Says Vietnam, The Star, 19 January 2021, available at: https://www.thestar.com.my/aseanplus/aseanplusnews/2021/01/19/asean-well-prepared-to-accelerate-growth-of-digital-economy-saysvietnam, accessed on 1 March, 2021.

Association of the Southeast Asian Nations (ASEAN), ASEAN Overtakes EU to Become China's Top Trading Partner in Q1, 15 May, 2020. Available at: https://www.aseanbriefing.com/news/asean-overtakes-eu-become-chinas-top-trading-partnerq1-2020/, accessed on 1 March, 2021. 
Association of the Southeast Asian Nations (ASEAN), Chairman's Statement of the 23rd ASEAN-Japan Summit, ASEAN, 12 November, 2020, available at: https://www.asean2020.vn/documents/225899/226554/20201124000622.342.pdf/53d283c16bb0-4b57-8d7f-6da043f4dc26, accessed on 1 March, 2021.

Association of the Southeast Asian Nations (ASEAN), Risk Assessment for International Dissemination of COVID-19 to the ASEAN Region, ASEAN Biodiaspora Virtual Center $(A B V C)$, 4 January, 2021, available at: https://asean.org/storage/COVID-19_Report-ofASEAN-BioDiaspora-Regional-Virtual-Center_4January2021.pdf, accessed on 1 March, 2021.

Carey Finn, Japan's Travel Bubble: What Is It, and Who's Included? Tokyo Cheapo, 21 March, 2021, available at: https://tokyocheapo.com/travel/japan-travel-bubbles/, accessed on 26 March, 2021.

Center for Strategic \& International Studies (CSIS), Southeast Asia COVID-19 Tracker, CSIS, March 2021, available at: https://www.csis.org/programs/southeast-asia-program/southeastasia-covid-19-tracker-0, accessed on 1 March, 2021.

Centers for Disease Control and Prevention (CDC), About Variants of the Virus that Causes COCID-19, CDC, 12 February, 2021, available at: https://www.cdc.gov/coronavirus/2019ncov/transmission/variant.html\#: :text=Multiple\%20COVID\%2D19\%20variants\%20are,or\% 20increased\%20risk\%20of\%20death, accessed on 1 March, 2021.

Dian Septiari, Leaders Support the Establishment of Covid-19 Response Fund, The Jakarta Post, 14 April 2020, available at: https://www.thejakartapost.com/seasia/2020/04/14/leaderssupport-establishment-of-asean-covid-19-response-fund.html, accessed on 1 March, 2021.

Ferdinal M. Fernando, Jennifer Frances E. De La Rosa, and Mary Kathleen Quiano-Castro, COVID-19: A Collective Response in ASEAN, The ASEAN Magazine, 1 May, 2020, available at: https://asean.org/storage/2017/09/The-ASEAN-Magazine-Issue-1-May-2020.pdf, accessed on 1 March, 2021.

Four ASEAN nations among 38 to get Avigan drug from Japan for clinical trial, The Star, 29 April 2020, available at: https://www.thestar.com.my/news/regional/2020/04/29/four-aseannations-among-38-to-get-avigan-drug-from-japan-for-clinical-trial, accessed on 1 March, 2021.

Hazlin Hassan, COVID-19 Crisis Taking a Toll on Malaysians' Mental Health, The Straits Times, 27 July, 2020, available at: https://www.straitstimes.com/asia/se-asia/covid-19-crisistaking-a-toll-on-malaysians-mental-health, accessed on 1 March, 2021.

James Gallagher, New Coronavirus Variant: What Do We Know? BBC, 20 December 2020, available at: https://www.bbc.com/news/health-55388846, accessed on 1 March, 2021.

Japan International Cooperation Agency (JICA), Emergency Assistance to Counter with Coronavirus in Myanmar - Providing a Primer (Testing Kit) to the National Health Laboratory (NHL.), JICA, 25 February 2020, available at: https://www.jica.go.jp/myanmar/english/office/topics/press200225.html, accessed on 1 March, 2021. 
Japan-ASEAN Integrated Fund (JAIF), A Feasibility Study on the Establishment of "ASEAN Centre for Public Health Emergencies and Emerging Diseases", JAIF, 31 August, 2020, available at: https://jaif.asean.org/project-brief/a-feasibility-study-on-the-establishment-ofasean-centre-for-public-health-emergencies-and-emerging-diseases/, accessed on 1 March, 2021.

Melissa Healy, New Evidence that U.K. Coronavirus Variant Spreads More Easily has Scientists Really Worried, Los Angeles Times, 10 January, 2021, available at: https://www.latimes.com/science/story/2021-01-10/new-evidence-that-u-k-coronavirusvariant-spreads-more-easily-has-scientists-really-worried, accessed on 1 March, 2021.

Ministry of Foreign Affairs of Japan (MOFA), Japan-ASEAN Connectivity Initiative, MOFA, 2020, available at: https://www.mofa.go.jp/files/100114591.pdf, accessed on 1 March, 2021. Ministry of Foreign Affairs of Japan, 23rd Japan-ASEAN Summit Meeting, Ministry of Foreign Affairs of Japan, 12 November, 2020, available at: https://www.mofa.go.jp/a_o/rp/page3e_001075.html,accessed on 1 March, 2021.

Ministry of Foreign Affairs, Senior Officials' Meetings of APT, EAS and ARF Take Place. Republic of Korea's Ministry of Foreign Affairs, 23 July, 2020, available at: http://www.mofa.go.kr/eng/brd/m_5676/view.do?seq=321169\&srchFr=\&amp;srchTo=\&amp ;srchWord=\&amp;srchTp=\&amp;multi_itm_seq=0\&amp;itm_seq_1=0\&amp;itm_seq_2=0\& amp;company_cd=\&amp;company_nm=\&page=1\&titleNm=, accessed on 1 March, 2021 .

Nina T Castilo-Carandang, Robert D Buenaventura, Yook-Chin Chia, et al., "Moving Towards Optimized Non-Communicable Disease Management in the ASEAN Region: Recommendations from a Review and Multidisciplinary Expert Panel", Risk Manag Health Policy, 2020, available at: https://pubmed.ncbi.nlm.nih.gov/32765135/, accessed on 1 March, 2021.

PayPal, PayPal Global Freelancer Survey, PayPal, 1 March, 2018, available at: https://www.paypal.com/stories/sea/paypal-global-freelancer-survey, accessed on 1 March, 2021.

Sithanonxay Suvannaphakdy, ASEAN Single Window: Time to Enlarge the Aperture, Yusof Ishak Institute of Southeast Asian Studies (ISEAS), 17 July, 2020, available at: https://www.iseas.edu.sg/media/commentaries/asean-single-window-time-to-enlarge-theaperture/, accessed on 1 March, 2021.

The ASEAN Secretariat, ASEAN Key Figures 2019, ASEAN, 15 October, 2019, available at: https://www.aseanstats.org/wp-content/uploads/2019/11/ASEAN_Key_Figures_2019.pdf, accessed on 1 March, 2021.

The ASEAN Secretariat, ASEAN Rapid Assessment: The Impact of COVID-19 on Livelihoods Across ASEAN, Jakarta: The ASEAN Secretariat, 23 November, 2020, available at: https://asean.org/storage/ASEAN-Rapid-Assessment Final-23112020.pdf, accessed on 1 March, 2021.

The Vaccine Alliance (GAVI), Japan Pledges USD 130 million to Support Global Access to COVID-19 Vaccines, GAVI, 12 April, 2020, available at: https://www.gavi.org/news/media- 
room/japan-pledges-us-130-million-support-global-access-covid-19-vaccines, accessed on 1 March, 2021.

United Nations Economic and Social Commission for Asia and the Pacific (UNESCAP), The Impact and Policy Responses for COVID-19 in Asia and the Pacific. United Nations, July 2020, available at: $\quad$ https://www.unescap.org/sites/default/d8files/knowledgeproducts/COVID\%20_Report_ESCAP.pdf, accessed on 1 March, 2021.

United Nations Office for Disaster Risk Reduction (UNDRR), General Assembly puts the Sendai Framework at the Centre of COVID-19 Response and Recovery Policy, UNDRR, 21 September, 2020, available at: https://www.undrr.org/news/general-assembly-puts-sendaiframework-centre-covid-19-response-and-recovery-policy, accessed on $1 \mathrm{March}, 2021$.

Victor D. Cha, "Globalization and the Study of International Security," Journal of Peace Research, Vol. 37. No. 3. 2000, pp. 391-403.

Victoria Y Fan, Dean T Jamison, and Lawrence H Summers, 'The Loss from Pandemic Influenza Risk,' in James D T, Gelband H, Horton S, et al., eds., Disease Control Priorities: Improving Health and Reducing Poverty, 3rd edition, Washington D.C.: The World Bank, 2017, available at: https://www.ncbi.nlm.nih.gov/books/NBK525291/, accessed on 1 March, 2021.

World Bank. East Asia and Pacific in the Time of COVID-19: East Asia and Pacific Economic Update - April 2021, World Bank: Washington, DC, 2021.

World Health Organization (WHO), COVID-19 Weekly Epidemiological Update, WHO, 28 February, 2021, available at: https://covid19.who.int/, accessed on 1 March, 2021.

World Health Organization (WHO), SARS-CoV-2 Variant - United Kingdom of Great Britain and Northern Ireland, WHO, 21 December, 2020, available at: https://www.who.int/csr/don/21-december-2020-sars-cov2-variant-united-kingdom/en/, accessed on 1 March, 2021;

World Health Organization (WHO), Statement - Where Do We Stand Today on COVID-19, and What Have We Learned?, WHO, 8 April, 20220, available at: https://www.euro.who.int/en/media-centre/sections/statements/2020/statement-where-do-westand-today-on-covid-19,-and-what-have-we-learned, accessed on 1 March, 2021.

Yuki Fukuoka, Supply Chain Transformation Underway in Southeast Asia - Production Shift Due to Us-China Conflict and Strengthened Resilience in Response to the Covid-19 Pandemic, Mitsui \& Co. Global Strategic Studies Institute, 18 September, 2020, available at: https://www.mitsui.com/mgssi/en/report/detail/__icsFiles/afieldfile/2020/09/18/2008c_fukuo ka_e.pdf, accessed on 1 March, 2021. 